\title{
HUBUNGAN SIKAP KERJA, MOTIVASI DAN KEPEMIMPINAN DENGAN KINERJA STAF PADA UNIVERSITAS MUHAMMADIYAH TANGERANG (UMT)
}

\author{
Sugeng Siswondo \\ UNIVERSITAS MUHAMMADIYAH PROF.DR.HAMKA
}

\begin{abstract}
ABSTRAK
Sugeng Siswondo, Hubungan Sikap Kerja, Motivasi Dan Kepemimpinan dengan Kinerja Staf Pada Universitas Muhammadiyah Tangerang (UMT). Studi Kuantitatif Pada Program Studi Manajemen Universitas Muhammadiyah Prof. DR. HAMKA (UHAMKA). Tesis. Program Studi Manajemen, Sekolah Pascasarjana Universitas Muhammadiyah Prof. DR. HAMKA, September 2015.Tujuan penelitian adalah untuk mengetahui apakah terdapat hubungan Sikap Kerja, Motivasi dan Kepemimpinan dengan Kinerja Staf Pada UMT . Methode penelitian yang digunakan adalah methode penelitian Survei. Responden adalah Staf pada UMT. Type penelitian ini adalah penelitian penjelasan (explanatory research), karena penelitian ini menjelaskan hubungan Sikap Kerja, motivasi dan Kepemimpinan dengan Kinerja Staf. Pengumpulan data dilakukan melalui kuisioner. Analisis data menggunakan analisis regresi berganda.Hasil penelitian menunjukan bahwa Sikap Kerja, motivasi dan Kepemimpinan berhubungan dengan pruduktivitas kerja Staf UMT, dengan kontribusi determinasi $\left(\mathrm{R}^{2}\right)$ sebesar 0,264 atau 26,4\%, Dijelaskan oleh variabel lain diluar konsep penelitian dan persamaan regresi yang dihasilkan adalah $\mathrm{Y}=56,033+0,322 \mathrm{X}_{1}+0,119 \mathrm{X}_{2}-0,210 \mathrm{X}_{3}$. Hasil penelitian menunjukan bahwa variabel sikap kinerja lebih kuat berhubungan dengan Kinerja Staf UMT yaitu sebesar 0,322, sedangkan hubungan variabel Sikap Kerja sebesar 0,322 dan hubungan variabel Kepemimpinan sebesar -0,210.Dari hasil penelitian juga disimpulkan bahwa Kinerja Staf UMT akan semakin meningkat apabila Sikap Kerja, motivasi, dan Kepemimpinan lebih baik. Sikap Kerja dapat ditingkatkan dengan memberikan pelatihan Sikap Kerja yang lebih bermutu lagi, Motivasi dapat dilakukan dengan mendorong Staf untuk melakukan karya inovatif, memberikan penghargaan kepada Staf yang berprestasi dan secara bersama-sama membuat rencana dan menetapkan tujuan yang dicapai lembaga.
\end{abstract}

\section{Latar Belakang}

Era globalisasi dalam dunia terbuka dan perdagangan bebas yang semakin tanpa batas menuntut setiap negara harus lebih efektif dan efisien dalam meningkatkan daya saing yang semakin kompetitif. Kinerja setiap individu merupakan alternatif yang tidak bisa ditunda lagi bila ingin bersaing secara regional maupun global. Tuntutan kerja tersebut juga terjadi pada sumber daya manusia pelayanan pendidikan baik lembaga pendidikan negeri maupun swasta.

Visi Sistem Pendidikan Nasional, merupakan wujud masyarakat edukatif yang menjadi harapan bangsa kita di masa yang akan datang. Salah satu upaya untuk mewujudkan masyarakat tersebut, maka ditetapkan misi pembangunan dibidang pendidikan, yaitu dengan memelihara dan meningkatkan pelayanan pendidikan yang bermutu, merata dan melibatkan partisipasi masyarakat. Agar misi pembangunan dibidang pendidikan tersebut dapat dilaksanakan secara efektif dan efisien, maka disusun strategi pembangunan dibidang pendidikan yaitu dengan peningkatan kualitas sumber daya manusia pendidikan yaitu dengan peningkatan kinerja dan produktifitas kerja bagi tenaga pendidikan.

Kinerja tenaga pendidikan khususnya staf sebagai ujung tombak pelayanan pendidikan di lapangan merupakan masalah yang sangat penting untuk dikaji dalam rangka mempertahankan dan meningkatkan mutu pelayanan pendidikan. Kinerja staf yang baik merupakan salah satu jawaban untuk meningkatkan dan mempertahankan kualitas pelayanan pendidikan yang di berikan dengan masyarakat. Kunci utama dalam peningkatan kualitas pelayanan pendidikan adalah staf pendidikan yang mempunyai kompetensi, kinerja yang tinggi dalam memberikan pelayanan dan pengolahan dalam untuk terlaksananya pendidikan.

Kinerja yang dihasilkan staf tidak lepas dari faktor yang mempengaruhinya. Menurut Gibson Jl, JM Ivancevich, dan Donelly Junior (1997: 15) menjelaskan

bahwa ada tiga kelompok variabel yang mempengaruhi perilaku kerja, yang selanjutnya berefek kepada kinerja staf yaitu: variabel individu, psikologis dan organisasi. Lebih lanjut Gibson Ivancevich, dan Donelly Junior menjelaskan bahwa faktor individu yang mempengaruhi perilaku kerja adalah kemampuan dan ketrampilan, latar belakang dan demografis. Adapun faktor psikologis terdiri dari persepsi, sikap, kepribadian, belajar dan motivasi.

Selanjutnya, faktor organisasi terdiri dari sumber daya, komunikasi, kepemimpinan, imbalan, struktur dan rancangan kerja Menurut Schermerhorn yang dikutip Marihot Tua Efendi Hariandja (2002: 346) mengatakan bahwa perilaku kerja seseorang merupakan perkalian dari atribut individu, tingkat usaha, dan dukungan organisasi. Atribut individu yang dimaksud berupa kemampuan dan ketrampilan. Dukungan organisasi berupa situasi yang mendukung dengan berbagai sistem keorganisasian yang di ciptakan, ketersediaan peralatan, dan lain-lain. Dan tingkat usaha adalah yang dilakukan oleh seseorang dalam melakukan suatu pekerjaan tertentu. Menurut Timpe (1998: 9) faktor-faktor yang mempengaruhi kinerja seseorang adalah supervisi, lingkungan kerja, perilaku, manajemen, desain jabatan, umpan balik, dan administrasi pengupahan.

Sebagai tenaga yang profesional, staf pengelola pendidikan memiliki kemampuan atau kompetensi yang berbeda-beda antara staf yang satu dengan lainnya. Dimensi kompetensi dosen menurut Etty Kartikawati (1993: 24) dibedakan menjadi tiga yaitu kompetensi profesional, kompetensi personal dan kompetensi sosial.

Kompetensi staf ditunjukkan dari perilaku staf dalam memberikan pelayanan pendidikan berdasarkan standar pelayanan pendidikan, mandiri, bertanggung jawab, dan mengembangkan kemampuan sesuai dengan kebutuhan, serta menggunakan berbagai strategi yang tepat dalam proses menghadapi mahasiswa. Agar staf dalam 
mengelola kegiatan pembelajaran dapat berhasil dengan maksimal, maka diperlukan sikap kerja atau kemampuan kerja dalam mengatur diri maupun mengelola diri dengan menemukan siasat dan teknik-teknik tertentu dalam proses pelayanan sehingga memudahkan mahasiswa dalam proses kebutuhan data bagi mahasiswa, dosen dan yang lainnya yang memerlukan data tentang perkulihan. Dengan kompetensi yang dimiliki maka staf akan dapat mengatur diri, mengelola diri, menggerakkan dirinya ke arah kemandirian. Ciri kompetensi staf tersebut harus tetap dipelihara dan ditingkatkan dalam rangka mempertahankan mutu pelayanan pendidikan

Kinerja staf dan hasilnya juga sangat ditentukan oleh faktor psikologis staf tersebut yaitu sikap kerja. Berdasarkan kenyataan di lapangan menunjukkan, seorang staf yang mempunyai sikap kerja tinggi tidak menjamin keberhasilan dalam pelayanan dan pengolahan yang diperlukan dalam perkulihan, namun seorang staf yang sikap kerja sedang tetapi motivasinya tinggi lebih besar peluang keberhasilannya dalam kegiatan pelayanan dan pengolahan administrasi pembelajaran.

Hubungan yang erat antara sikap kerja dan motifasi adalah sikap kerja staf sebagai realita dari staf akan dapat menunjukkan hasil yang lebih optimal apabila diawali dengan kepemimpinan atasan staf sebagai persepsi menghadapi situasi didalam kehidupan sehari-hari.

Selain itu, faktor eksternal juga sangat mempengaruhi staf dalam menghasilkan kinerja. Faktor eksternal tersebut adalah adanya dukungan pimpinani. Dukungan pimpinan dalam pelayanan pendidikan, maupun bidang jasa lainnya dalam peningkatan kinerja staf salah satunya ditentukan oleh suasana dalam kepemimpinan yang diciptakan oleh tata hubungan atau komunikasi yang berlaku dilingkungan tempat kerja.

Lingkungan kerja yang menyenangkan merupakan bagian penting yang mendukung kinerja staf. Pimpinan perlu memperhatikan apakah pekerjaan yang dibebankan kepada staf sudah proporsional atau berlebihan. Beban kerja yang berlebihan yang tidak didukung oleh fasilitas kerja yang memadai dapat menimbulkan tekanan psikologis pada staf sehingga menimbulkan ketidakpuasan staf dalam bekerja. Sebaliknya, kondisi yang tidak menyenangkan dalam lingkungan kerja staf mempunyai dampak yang luas dengan kehidupan organisasi, yaitu akan menimbulkan masalah dalam kerja misalnya konflik antar staf, bahkan akan menghambat keberhasilan kerja.

Di era otonomi daerah dan berlakunya otonomi pendidikan yang sekarang ini sedang dilaksanakan memiliki nilai tersendiri bagi daerah untuk berkompetisi dalam mengelola segala sesuatu tentang mutu pendidikan.

Kewenangan tersebut memiliki nilai strategis bagi organisasi pendidikan untuk mendobrak kebekuan dan stagnasi yang telah di alami dan melingkupi selama ini dalam hal kualitas sumber daya manusia pendidikan. Di samping itu, suatu lembaga pendidikan baik lembaga pendidikan negeri maupun swasta pada era otonomi sekarang ini juga dihadapkan pada tantangan yang berupa kemandirian untuk mengatur internalisasi organisasi pendidikan. Kemandirian tersebut adalah kemampuan organisasi pelayanan pendidikan untuk membiayai operasional pelayanan pendidikan.

Selain itu, organisasi pelayanan pendidikan baik lembaga pendidikan negeri maupun swasta di era otonomi saat ini, menghadapi dua tuntutan yang secara simultan yaitu tuntutan masyarakat untuk mendapatkan pelayanan pendidikan yang bermutu dengan harga yang terjangkau, dan sulitnya untuk mendapatkan staf yang profesional untuk memberikan pelayanan pendidikan yang bermutu tersebut. Hal ini sesuai pendapat yang disampaikan oleh Dardji Darmodiharjo (1983:5) yang menjelaskan bahwa salah satu permasalahan pendidikan yang dihadapi sekarang ini adalah rendahnya mutu pelayanan pendidikan pada setiap jenjang dan satuan pendidikan.

Menurut Mendiknas RI (2005), subsidi keuangan dari pemerintah pusat pada tahun anggaran 2005 di sektor pendidikan hanya $20 \%$. Rendahnya subsidi keuangan tersebut sebagian besar oleh organisasi pelayanan pendidikan masih digunakan untuk beaya operasional pendidikan. Kondisi yang demikian, menuntut organisasi pendidikan harus mampu menggali setiap potensi yang ada untuk meningkatkan mutu pendidikan termasuk peningkatan kualitas sumber daya manusia pendidikan.

Perkembangan studi lanjut pendidikan untuk staf administrasi saat ini tersedia cukup banyak jenjang seperti studi lanjut ke jenjang sekolah menengah atas atau pendidikan S1. Dengan jenjang studi lanjut tersebut, tentunya dapat memberikan warna tersendiri dalam menghasilkan staf yang berkinerja tinggi dalam meningkatkan mutu pelayanan pendidikan. Akan tetapi, kenyataannya justru juga memberikan permasalahan sendiri dengan pelayanan yang dihasilkan yaitu kualitas staf yang dihasilkan institusi pendidikan tersebut belum memenuhi persyaratan staf yang profesional.

Sebagai unsur tenaga pendidik, profesi staf mempunyai fungsi ganda yaitu fungsi staf sebagai pelaksana pelayanan pendidikan, pengelola dalam bidang pelayanan pendidikan, pembuat administrasi, dan pengolahan data yang diperlukan oleh instansi pendidikan seperti universitas sebagai pengembang keilmuan. Mereka diharapkan mempunyai kinerja yang baik dan profesional dalam fungsi tersebut untuk mencapai tujuan pelayanan dan pengelolahan pendidikan. Tentu tugas dan kewajiban tersebut bukan hal yang mudah untuk dicapai.

Berdasarkan pengamatan dan masukan dari beberapa teman staf pelayanan dan pengelolahan di Universitas Muhammadiyah Tangerang (UMT), dengan paradigma baru saat ini, masih ditemukan staf yang bekerja sekedar untuk mencari nafkah guna menghidupi keluarga, bekerja dengan malas-malasan, masuk kerja tidak tepat waktu dan bekerja sebagai formalitas tanpa ada rasa bersalah kepada masyarakat.

Kecenderungan ada staf yang berbuat seperti tersebut di atas adalah bukan semata-mata kesalahan staf itu saja, ada kemungkinan diduga karena pihak tempat dimana bekerja kurang memperhatikan kondisi-kondisi yang memungkinkan tumbuhnya nilai-nilai kerja pada diri staf.

Pembinaan staf dapat kita bina atau kita didik dengan waktu yang relatif lebih cepat dari pada kalau kita mendidik atau mengubah sikap kerja staf. Karena sikap seseorang itu sulit sekali di ubah kalau bukan berasal dari kesadaran diri sendiri.

Selanjutnya di kemukakan oleh MC Gregor berasumsi bahwa manusia tidak memiliki sikap bawaan yang tidak menyukai pekerjaan. Dalam kondisi tertentu manusia mampu mencapai tujuan dan tanggung jawab tanpa 
adanya paksaan. Kinerja merupakan hasil kerja seseorang yang pada giliranya akan menentukan keseluruhan dan keberhasilan faktor-faktor yang berpengaruh. Apabila dilihat dari tingkat kedisiplinan kerja seseorang staf, kita dapat mengetahui sebaik mana sikap kerja mereka dengan instansi pendidikan tempat mereka bekerja.

Kinerja yang baik, merupakan suatu langkah untuk menuju tercapainya tujuan instansi oleh karena itu diupayakan untuk meningkatkan kinerja, namun hal tersebut tidak mudah, karena banyak faktor yang mempengaruhi naik turunya kinerja seseorang, staf yang mempunyai kedisiplinan kerja yang tinggi akan menunjukan sikap kerja yang baik dalam bekerja.

Selain faktor kerja, pemimpin dapat mempengaruhi moral, kepuasan kerja, keamanan, kualitas kehidupan kerja terutama tingkat kerja suatu staf. Kemampuan dan ketrampilan kepemimpinan dalam pengarahan adalah faktor penting efektivitas memimpin. Bila organisasi dapat mengidentifikasi kualitas perilaku dan teknik yang berhubungan dengan kepemimpinan, kemampuan untuk menyeleksi pemimpin-pemimpin yang efektif akan meningkat, berbagai perilaku dan teknik tersebut akan dapat dipelajari.

Penilaian kinerja (performance appraisal) adalah proses melalui mana organisasi-organisasi mengevaluasi atau menilai prestasi kerja staf .Kegiatan ini dapat memperbaiki keputusan yang salah dan memberikan umpan balik kepada para staf tentang pelaksanaan kerja mereka. Kegunaan kegunaan penilaian kinerja kerja staf dapat di rinci sebagai berikut, perbaikan kinerja kerja staf.

Penyimpangan-penyimpangan proses staffing, ketidak akuratan informasional, kesalahan desain pekerjaan, kesempatan kerja yang adil dan tatangan eksternal. Kepemimpinan merupakan salah satu bagian manajemen Lebih lanjut, Siagian mengemukakan bahwa kepemimipinan memainkan peranan yang dominan krusial, dan kritikal dalam keseluruhan upaya untuk meningkatkan kinerja kerja, baik pada tingkat individu, tingkat kelompok, dan pada tingkat organisasi.

Pemimpin pada hakekatnya merupakan salah satu fungsi manajer disamping fungsi planning, organizing, dan controlling, dalam melaksanakan serangkaian fungsi pemimpin (leader) harus selalu mampu memberikan petunjuk, bimbingan dan pengarahan kepada bawahan, seorang pemimpin tidak mungkin dan tidak bisa bekerja sendiri tanpa adanya kerjasama dengan bawahan, sebagian seorang pemimpin harus mampu menciptakan suasana kerja yang sebaik baiknya (proper atmospher), harus memenuhi apa yang di harapkan bawahan, sehingga para bawahan dapat bekerja dengan sebaik baiknya. Disisi yang lain, Ordway Tead menjelaskan bahwa kepemimpinan adalah aktivitas mempengaruhi orangorang agar mau bekerjasama untuk mencapai beberapa tujuan yang mereka inginkan. Sementara Paul Hersey dan Kenneth H. Blanchard mengartikan kepemimpinan sebagai proses mempengaruhi kegiatan individu atau kelompok dalam usaha mencapai tujuan

Selain itu Transparansi kepemimpinan merupakan faktor penting dalam memberikan pengarahan kepada staf, maka kepemimpinan yang dibutuhkan adalah kepemimpinan yang bisa menumbuhkan motivasi kerja staf, karena dapat menumbuhkan rasa kepercayaan diri staf dalam menjalankan tugasnya masing masing.
Berdasarkan uraian diatas menunjukan penilaian kinerja merupakan suatu hal yang tidak dapat dipisahkan dengan instansi pendidikan. Dukungan dari tiap manajemen yang berupa pengarahan, dukungan sumber daya seperti memberikan peralatan yang memadai sebagai sarana untuk memudahkan pencapaian tujuan yang ingin dicapai dalam pendampingan, bimbingan, pelatihan, serta pengembangan akan lebih mempermudah penilaian kinerja yang obyektif.

Tuntutan kopetensi staf semakin menjadi kebutuhan, peningkatan profesionalisme staf harus ditunjang dengan integritas yang tinggi, dengan mengupayakan terwujudnya karakteristik sebagai berikut :

1. Melaksanakan tugas dengan terampil, kreatif dan inovatif.

2. Mempunyai komitmen yang kuat dengan tugas dan program.

3. Komitmen dengan pelayanan umum.

4. Bekerja berdasarkan sifat dan etika profesional menjadi daya tanggap (Responsiveness) dan akuntabilitas (accountability)

5. Memiliki derajat otonomi yang penuh dengan tanggung jawab dalam membuat keputusan.

6. Memiliki efisiensi dan kreativitas

Berdasarkan beberapa substansi permasalahan yang diuraikan diatas, maka dipandang perlu untuk melakukan penelitian tentang hubungan sikap kerja, motivasi kerja dan kepemimpinan dengan kinerja staf pada Universitas Muhammadiyah Tangerang.

\section{Metode Penelitian}

Data kuantitatif yaitu penelitian kuantitatif yang berdasarkan studi deskriptif dimana penelitian ini berhubungan dengan masalah-masalah berupa fakta-fakta saat ini. Analisis kuantitatif merupakan analisis yang digunakan terhadap data yang berwujud angka-angka dan cara pembahasannya dalam penelitian ini menggunakan aplikasi program SPSS (Statistic Pakcagge for the Sosial Science) Versi 21. Penelitian dilakukan dengan cara datang langsung pada Universitas Muhammadiyah Tangerang dimana penulis melakukan penelitian dan melakukan interview serta observasi yang berkaitan dengan permasalahan serta meminta dokumen-dokumen pendukung sebagai bahan untuk melengkapi penulisan Tesis

\section{Uji Hipotesis}

Pengujian hipotesis dilakukan untuk memperoleh jawaban tentang rumusan masalah penelitian yang belum dibuktikan kebenarannya. Pengujian hipotesis pada penelitian ini dilakukan dengan beberapa tahapan yakni:

\section{a. Hipotesis pertama $\left(X_{1} Y\right)$}

$\mathrm{H}_{0}: \mathrm{b}_{1}=0$ : tidak terdapat hubungan sikap kerja terhadap kinerja staf.

$\mathrm{H}_{\mathrm{a}}: \mathrm{b}_{1} \neq 0$ : terdapat hubungan sikap kerja terhadap kinerja staf.

Jika $t_{\text {hitung }}>\mathrm{t}_{\text {tabel, }}$ maka $\mathrm{H}_{0}$ ditolak dan $\mathrm{H}_{\mathrm{a}}$ diterima.

1) Uji t (t-test)

Berdasarkan hasil perhitungan dengan bantuan komputer program SPSS 21 for windims diperoleh nilai $t_{\text {hitung }}$ sebesar 3,901 dan $t_{\text {tabel }}$ pada df 80 sebesar 1,67. Ini berarti $\mathrm{t}_{\text {hitung }}>\mathrm{t}_{\text {tabel }}$ atau 3,901 $>1,67$.

Maka $\mathrm{H}_{0}$ ditolak dan $\mathrm{H}_{\mathrm{a}}$ diterima, yang berarti terdapat hubungan signifikan sikap kerja terhadap kinerja staf. Dengan demikian hipotesis terbukti. 


\section{2) Uji koefisien korelasi dan determinasi}

Berdasarkan hasil perhitungan SPSS 21 for windows diperoleh nilai koefisien korelasi sebesar 0,398. Sedangkan nilai koefisien determinasi yang diperoleh adalah sebesar 0,158 atau $15,8 \%$. Hal ini menunjukan persentase hubungan variabel sikap kerja terhadap kinerja staf sebesar $15,8 \%$. Sedangkan sisanya sebesar $84,2 \%$ dihubungani variabel lain yang tidak diteliti dalam penelitian ini.

3) Persamaan linear sederhana

Persamaan linear yang diperoleh dalam analisis ini adalah:

$\hat{\mathrm{Y}}=\mathrm{a}+\mathrm{b}_{1} \mathrm{X}_{1}$

$\hat{\mathrm{Y}}=51,748+0,305 \mathrm{X}_{1}$

Dari persamaan di atas, berarti setiap kenaikan 1 skor variabel sikap kerja dapat meningkatkan skor kinerja staf sebesar 0,305 dengan asumsi variabel motivasi dan kepemimpinan konstan.

\section{b. Hipotesis kedua $\left(\mathrm{X}_{2} \mathrm{Y}\right)$}

$\mathrm{H}_{0}: \mathrm{b}_{2}=0$ : tidak terdapat hubungan motivasi terhadap kinerja staf.

$\mathrm{H}_{\mathrm{a}}: \mathrm{b}_{2} \neq 0$ : terdapat hubungan motivasi terhadap kinerja staf.

Jika $\mathrm{t}_{\text {hitung }}>\mathrm{t}_{\text {tabel, }}$ maka $\mathrm{H}_{0}$ ditolak dan $\mathrm{H}_{\mathrm{a}}$ diterima.

1) Uji t (t-test)

Berdasarkan hasil perhitungan dengan bantuan komputer program SPSS 21 for windims diperoleh nilai $t_{\text {hitung }}$

sebesar 3,188 dan $t_{\text {tabel }}$ pada df 80 sebesar 1,67. Ini berarti $\mathrm{t}_{\text {hitung }}>\mathrm{t}_{\text {tabel }}$ atau 3,188 $>1,67$.

Maka H0 ditolak dan Ha diterima, yang berarti terdapat hubungan signifikan motivasi terhadap kinerja staf. Dengan demikian hipotesis terbukti.

2) Uji koefisien korelasi dan determinasi

Berdasarkan hasil perhitungan SPSS 21 for windows diperoleh nilai koefisien korelasi sebesar 0,334. Sedangkan nilai koefisien determinasi yang diperoleh adalah sebesar 0,111 atau $11,1 \%$. Hal ini menunjukan persentase hubungan variabel motivasi terhadap kinerja staf sebesar $11,1 \%$. Sedangkan sisanya sebesar $88,9 \%$ dihubungani variabel lain yang tidak diteliti dalam penelitian ini.

3) Persamaan linear sederhana

Persamaan linear yang diperoleh dalam analisis ini adalah:

$\hat{\mathrm{Y}}=\mathrm{a}+\mathrm{b}_{2} \mathrm{X}_{2}$

$\hat{Y}=58,810+0,182 X_{2}$

Dari persamaan di atas, berarti setiap kenaikan 1 skor variabel motivasi dapat meningkatkan skor kinerja staf sebesar 0,182 dengan asumsi variabel sikap kerja dan kepemimpinan konstan.

\section{c. Hipotesis ketiga $\left(\mathrm{X}_{3} \mathrm{Y}\right)$}

$\mathrm{H}_{0}: \mathrm{b}_{3}=0$ tidak terdapat hubungan kepemimpinan terhadap kinerja staf.

$\mathrm{H}_{\mathrm{a}}: \mathrm{b}_{3} \neq 0$ : terdapat hubungan kepemimpinan terhadap kinerja staf.

Jika $t_{\text {hitung }}>\mathrm{t}_{\text {tabel, }}$ maka $\mathrm{H}_{0}$ ditolak dan $\mathrm{H}_{\mathrm{a}}$ diterima.

1) Uji t (t-test)

a) Berdasarkan hasil perhitungan dengan bantuan komputer program SPSS 21 for windims diperoleh nilai $t_{\text {hitung }}$ sebesar 0,773 dan $t_{\text {tabel }}$ pada df 80 sebesar 1,67. Ini berarti $t_{\text {hitung }}>t_{\text {tabel }}$ atau $0,773<1,67$.

b) Maka Ho diterima dan $\mathrm{Ha}$ ditolak, yang berarti terdapat hubungan signifikan kepemimpinan terhadap kinerja staf. Dengan demikian hipotesis tidak terbukti. 2) Uji koefisien korelasi dan determinasi

Berdasarkan hasil perhitungan SPSS 21 for windows diperoleh nilai koefisien korelasi sebesar -0,086. Sedangkan nilai koefisien determinasi yang diperoleh adalah sebesar 0,007 atau 0,7 \%. Hal ini menunjukan persentase hubungan variabel kepemimpinan terhadap kinerja staf sebesar $0,07 \%$. Sedangkan sisanya sebesar 99,93 \% dihubungani variabel lain yang tidak diteliti dalam penelitian ini.

3) Persamaan linear sederhana

Persamaan linear yang diperoleh dalam analisis ini adalah:

$\hat{\mathrm{Y}}=\mathrm{a}+\mathrm{b}_{3} \mathrm{X}_{3}$

$\hat{Y}=73,575+(-0,064) X_{3}$

Dari persamaan di atas, berarti setiap kenaikan 1 skor variabel kepemimpinan dapat meningkatkan skor kinerja staf sebesar -0,064 dengan asumsi variabel sikap kerja dan motivasi konstanta.

\section{d. Hipotesis ke empat $\left(X_{1} X_{2} Y\right)$}

$\mathrm{H}_{0}: \mathrm{b}_{1}=\mathrm{b}_{2}=0$ : tidak terdapat hubungan sikap kerja, dan motivasi secara bersama-sama terhadap kinerja staf.

$\mathrm{H}_{\mathrm{a}}$ : salah satu atau ketiga $\mathrm{b}_{1}, \mathrm{~b}_{2} \neq 0$ : terdapat hubungan sikap kerja, dan motivasi secara bersama-sama terhadap kinerja staf.

Jika $\mathrm{F}_{\text {hitung }}>\mathrm{F}_{\text {tabel, }}$ maka $\mathrm{H}_{0}$ ditolak dan $\mathrm{H}_{\mathrm{a}}$ diterima.

1) Uji F (F-test)

Berdasarkan hasil perhitungan dengan bantuan komputer program SPSS 21 for windims diperoleh nilai $t_{\text {hitung }}$ sebesar 9,742 dan $t_{\text {tabel }}$ pada df 80 sebesar 1,67. Ini berarti $\mathrm{F}_{\text {hitung }}>\mathrm{F}_{\text {tabel }}$ atau 9,742 $>1,67$.

Maka $\mathrm{H}_{0}$ ditolak dan $\mathrm{H}_{\mathrm{a}}$ diterima, yang berarti terdapat hubungan signifikan sikap kerja, dan motivasi secara bersamaan-sama terhadap kinerja staf. Dengan demikian hipotesis terbukti.

2) Uji koefisien korelasi dan determinasi

Berdasarkan hasil perhitungan SPSS 21 for windows diperoleh nilai koefisien korelasi sebesar 0,443. Sedangkan nilai koefisien determinasi yang diperoleh adalah sebesar 0,196 atau 19,6\%. Hal ini menunjukan persentase hubungan variabel sikap kerja, dan motivasi terhadap kinerja staf sebesar 19,6\%. Sedangkan sisanya sebesar 80,4\% dihubungani variabel lain yang tidak diteliti dalam penelitian ini.

3) Persamaan linear ganda

Persamaan linear yang diperoleh dalam analisis ini adalah:

$\hat{\mathrm{Y}}=\mathrm{a}+\mathrm{b}_{1} \mathrm{X}_{1}+\mathrm{b}_{2} \mathrm{X}_{2}$

$\hat{Y}=48,543+0,242 X_{1}+0,115 X_{2}$

Dari persamaan di atas dapat disimpulkan bahwa:

a) Setiap kenaikan 1 skor variabel sikap kerja dapat meningkatkan skor kinerja staf sebesar 0,242 dengan asumsi variabel kepemimpinan konstanta.

b) Setiap kenaikan 1 skor variabel motivasi dapat meningkatkan skor kinerja staf sebesar 0,115 dengan asumsi variabel sikap kerja dan kepemimpinan konstanta.

\section{e. Hipotesis ke lima $\left(\mathrm{X}_{1} \mathrm{X}_{3} \mathrm{Y}\right)$}

$\mathrm{H}_{0}: \mathrm{b}_{1}=\mathrm{b}_{3}=0$ : tidak terdapat hubungan sikap kerja dan kepemimpinan secara bersama-sama terhadap kinerja staf.

$H_{a}$ : salah satu atau ketiga $b_{1}, b_{3} \neq 0$ : terdapat hubungan sikap kerja dan kepemimpinan secara bersama-sama 
terhadap kinerja staf.

Jika $\mathrm{F}_{\text {hitung }}>\mathrm{F}_{\text {tabel, }}$ maka $\mathrm{H}_{0}$ ditolak dan $\mathrm{H}_{\mathrm{a}}$ diterima.

1) Uji F (F-test)

Berdasarkan hasil perhitungan dengan bantuan komputer program SPSS 21 for windims diperoleh nilai $t_{\text {hitung }}$ sebesar 11,526 dan $t_{\text {tabel }}$ pada df 80 sebesar 1,67. Ini berarti $F_{\text {hitung }}>F_{\text {tabel }}$ atau 11,526 $>1,67$.

Maka $\mathrm{H}_{0}$ ditolak dan $\mathrm{H}_{\mathrm{a}}$ diterima, yang berarti terdapat hubungan signifikan sikap kerja dan kepemimpinan secara bersamaan-sama terhadap kinerja staf. Dengan demikian hipotesis terbukti.

2) Uji koefisien korelasi dan determinasi

Berdasarkan hasil perhitungan SPSS 21 for windows diperoleh nilai koefisien korelasi sebesar 0,473. Sedangkan nilai koefisien determinasi yang diperoleh adalah sebesar 0,224 atau 22,4\%. Hal ini menunjukan persentase hubungan variabel sikap kerja dan kepemimpinan terhadap kinerja staf sebesar $22,4 \%$. Sedangkan sisanya sebesar $77,6 \%$ dihubungani variabel lain yang tidak diteliti dalam penelitian ini.

3) Persamaan linear ganda

Persamaan linear yang diperoleh dalam analisis ini adalah:

$\hat{\mathrm{Y}}=\mathrm{a}+\mathrm{b}_{1} \mathrm{X}_{1}+\mathrm{b}_{3} \mathrm{X}_{3}$

$\hat{Y}=59,193+0,386 X_{1}+(-0,206) X_{3}$

Dari persamaan di atas dapat disimpulkan bahwa:

a) Setiap kenaikan 1 skor variabel sikap kerja dapat meningkatkan skor kinerja staf sebesar 0,386 dengan asumsi variabel motivasi dan kepemimpinan konstanta.

b) Setiap kenaikan 1 skor variabel motivasi dapat meningkatkan skor kinerja staf sebesar -0,206 dengan asumsi variabel sikap kerja dan kepemimpinan konstanta.

\section{f. Hipotesis ke enam $\left(\mathrm{X}_{2} \mathrm{X}_{3} \mathrm{Y}\right)$}

$\mathrm{H}_{0}: \mathrm{b}_{2}=\mathrm{b}_{3}=0$ : tidak terdapat hubungan motivasi dan kepemimpinan secara bersama-sama terhadap kinerja staf.

$\mathrm{H}_{\mathrm{a}}$ : salah satu atau ketiga $\mathrm{b}_{2}, \mathrm{~b}_{3} \neq 0$ : terdapat hubungan motivasi dan kepemimpinan secara bersama-sama terhadap kinerja staf.

Jika $\mathrm{F}_{\text {hitung }}>\mathrm{F}_{\text {tabel, }}$ maka $\mathrm{H}_{0}$ ditolak dan $\mathrm{H}_{\mathrm{a}}$ diterima.

1) Uji F (F-test)

Berdasarkan hasil perhitungan dengan bantuan komputer program SPSS 21 for windims diperoleh nilai $t_{\text {hitung }}$ sebesar 6,117 dan $t_{\text {tabel }}$ pada df 80 sebesar 1,67. Ini berarti $F_{\text {hitung }}>F_{\text {tabel }}$ atau 6,117 $>1,67$.

Maka $\mathrm{H}_{0}$ ditolak dan $\mathrm{H}_{\mathrm{a}}$ diterima, yang berarti terdapat hubungan signifikan motivasi, dan kepemimpinan secara bersamaan-sama terhadap kinerja staf. Dengan demikian hipotesis terbukti.

2) Uji koefisien korelasi dan determinasi

Berdasarkan hasil perhitungan SPSS 21 for windows diperoleh nilai koefisien korelasi sebesar 0,364 Sedangkan nilai koefisien determinasi yang diperoleh adalah sebesar 0,133 atau 13,3\%. Hal ini menunjukan persentase hubungan variabel sikap kerja, motivasi, dan kepemimpinan terhadap kinerja staf sebesar $13,3 \%$. Sedangkan sisanya sebesar $86,7 \%$ dihubungani variabel lain yang tidak diteliti dalam penelitian ini.

3) Persamaan linear ganda

Persamaan linear yang diperoleh dalam analisis ini adalah:
$\hat{\mathrm{Y}}=\mathrm{a}+\mathrm{b}_{2} \mathrm{X}_{2}+\mathrm{b}_{3} \mathrm{X}_{3}$

$\hat{Y}=64,493+0,196 X_{2}+(-0,110) X_{3}$

Dari persamaan di atas dapat disimpulkan bahwa:

a) Setiap kenaikan 1 skor variabel sikap kerja dapat meningkatkan skor kinerja staf sebesar 0,196 dengan asumsi variabel motivasi dan kepemimpinan konstanta.

b) Setiap kenaikan 1 skor variabel motivasi dapat meningkatkan skor kinerja staf sebesar -0,110 dengan asumsi variabel sikap kerja dan kepemimpinan konstanta.

\section{g. Hipotesis ke tujuh $\left(X_{1} X_{2} X_{3} Y\right)$}

$\mathrm{H}_{0}: \mathrm{b}_{1}=\mathrm{b}_{2}=\mathrm{b}_{3}=0$ : tidak terdapat hubungan sikap kerja, motivasi dan kepemimpinan secara bersama-sama terhadap kinerja staf.

$\mathrm{H}_{\mathrm{a}}$ : salah satu atau ketiga $\mathrm{b}_{1}, \mathrm{~b}_{2}, \mathrm{~b}_{3} \neq 0$ : terdapat hubungan sikap kerja, motivasi dan kepemimpinan secara bersama-sama terhadap kinerja staf.

Jika $\mathrm{F}_{\text {hitung }}>\mathrm{F}_{\text {tabel, }}$ maka $\mathrm{H}_{0}$ ditolak dan $\mathrm{H}_{\mathrm{a}}$ diterima.

1) Uji F (F-test)

Berdasarkan hasil perhitungan dengan bantuan komputer program SPSS 21 for windims diperoleh nilai $t_{\text {hitung }}$ sebesar 9,462 dan $t_{\text {tabel }}$ pada df 80 sebesar 1,67. Ini berarti $F_{\text {hitung }}>F_{\text {tabel }}$ atau 9,462 $>1,67$.

Maka $\mathrm{H}_{0}$ ditolak dan $\mathrm{H}_{\mathrm{a}}$ diterima, yang berarti terdapat hubungan signifikan sikap kerja, motivasi, dan kepemimpinan secara bersamaan-sama terhadap kinerja staf. Dengan demikian hipotesis terbukti.

2) Uji koefisien korelasi dan determinasi

Berdasarkan hasil perhitungan SPSS 21 for windows diperoleh nilai koefisien korelasi sebesar 0,514. Sedangkan nilai koefisien determinasi yang diperoleh adalah sebesar 0,264 atau 26,4\%. Hal ini menunjukan persentase hubungan variabel sikap kerja, motivasi, dan kepemimpinan terhadap kinerja staf sebesar $26,4 \%$. Sedangkan sisanya sebesar $73,6 \%$ dihubungani variabel lain yang tidak diteliti dalam penelitian ini.

3) Persamaan linear ganda

Persamaan linear yang diperoleh dalam analisis ini adalah:

$\hat{\mathrm{Y}}=\mathrm{a}+\mathrm{b}_{1} \mathrm{X}_{1}+\mathrm{b}_{2} \mathrm{X}_{2}+\mathrm{b}_{3} \mathrm{X}_{3}$

$\hat{Y}=56,033+0,322 X_{1}+0,119 X_{2}+(-0,210) X_{3}$

Dari persamaan di atas dapat disimpulkan bahwa:

a) Setiap kenaikan 1 skor variabel sikap kerja dapat meningkatkan skor kinerja staf sebesar 0,322 dengan asumsi variabel motivasi dan kepemimpinan konstanta.

b) Setiap kenaikan 1 skor variabel motivasi dapat meningkatkan skor kinerja staf sebesar 0,119 dengan asumsi variabel sikap kerja dan kepemimpinan konstanta.

c) Setiap kenaikan 1 skor variabel kepemimpinan dapat meningkatkan skor kinerja staf sebesar -0,210 dengan asumsi variabel sikap kerja dan motivasi konstanta.

\section{Uji R dan $R^{2}$}

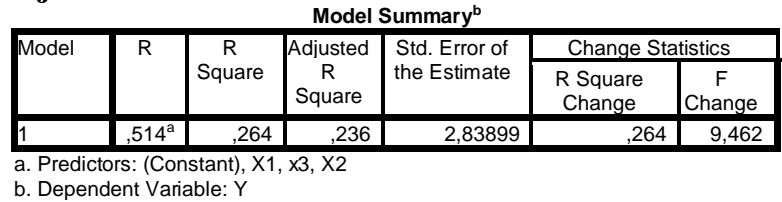

Sumber: out put SPSS, V. 21

Analisis: 
a. Kolom $\mathrm{R}$ menunjukan angka koefisien korelasi yaitu sebesar 0,514. Hal ini berarti hubungan antara sikap kerja, motivasi dan kepemimpinan adalah sangat kuat.

b. Kolom R Square menunjukan adalah 0,264 adalah pengkuadratan dari koefisien korelasi atau $0,514 \mathrm{x}$ $0,514=0,264$.

c. R Square disebut juga dengan koefisien determinasi. Hal ini berarti besarnya hubungan sikap kerja, motivasi dan kepemimpinan terhadap kinerja staf karyawan adalah sebesar 26,4\% sedangkan sisanya $(100 \%-26,4 \%=73,6 \%)$ dihubungani faktor lain.

\section{Uji Simultan}

\begin{tabular}{|l|c|r|r|l|l|}
\hline \multicolumn{7}{|c|}{ ANOVA $^{\mathrm{a}}$} \\
\hline Model & $\begin{array}{c}\text { Sum of } \\
\text { Squares }\end{array}$ & df & $\begin{array}{c}\text { Mean } \\
\text { Square }\end{array}$ & $\mathrm{F}$ & Sig. \\
\hline Regression & 228,791 & 3 & 76,264 & 9,462 &, $000^{\mathrm{b}}$ \\
1 Residual & 636,727 & 79 & 8,060 & & \\
\hline Total & 865,518 & 82 & & & \\
\hline
\end{tabular}

a. Dependent Variable: $Y$

b. Predictors: (Constant), X1, X3, X2

Sumber: out put SPSS, V. 21

Analisis :

Berdasarkan tabel diatas dapat diketahui bahwa uji Anova didapat $F_{\text {hitung }}$ sebesar 9,462 sedang $F_{\text {tabel }}$ 1,67 (dari jumlah variable dikurangi 1) 4 variabel $-1=3$ dan banyaknya sampel 83 didapat $F_{\text {tabel }} 1,67$ jadi $F_{\text {hitung }}>$ dari $F_{\text {tabel }}$ dengan demikian Ho ditolak dan Ha diterima, artinya terdapat hubungan linear antara variabel kedisiplinan kerja, motivasi dan kepemimpinan terhadap kinrja staf di Universitas Muhammadiyah Tangerang.

\section{B. Pembahasan hasil Penelitian}

\section{Berdasarkan Karakteristik Responden}

Berdasarkan hasil penelitian ditemukan sebagian besar Staf UMT Kota Tangerang adalah perempuan dibandingkan dengan staf laki-laki, yaitu sebesar 57,8\% atau 48 responden sedangkan untuk staf laki-lakinya sebesar 42,2 \% atau sebesar 35 responden. Hal ini mengindikasikan minat untuk menjadi staf masih didominasi oleh kaum perempuan, kenyataan ini berhubungan erat dengan pekerjaan sebagai staf yaitu, mencatat, merapihkan, dan membuat administrasi. namun demikian peran staf laki-laki masih sangat dibutuhkan, bahkan dalam pengembangan karir terutama untuk jabatan struktural masih didominasi oleh pihak laki-laki.

Ditinjau dari tingkat pendidikan staf-staf yang ada di UMT Kota Tangerang sebanyak 24,1\% atau 20 responden berpendidikan SMA, sedangka sebanyak 75,9\% atau 63 responsen telah berpendidikan Sarjana (S1). Hal ini menunjukan bahwa staf-staf UMT telah memiliki kualifikasi yang disyaratkan. Kualifikasi akademik adalah tingkat pendidikan minimal yang harus dipenuhi oleh seorang staf yang dibuktikan dengan ijazah dan/atau sertifikat keahlian yang relevan sesuai ketentuan perundang-undangan yang berlaku.

Berdasarkan tingkat usia sebagian besara staf-staf UMT Kota Tangerang berada pada usia antara 20 - 35 tahun sebesar 72,3\% atau 60 responden. kondisi ini mengindikasikan bahwa motivasi staf untuk berprestasi di UMT maksimal terutama dalam pengembangan profesinya melalui kegiatan-kegiatan mengikuti pelayanan terhadap dosen dan mahasiswa. Namun kinerja staf akan lebih meningkat apabila peran kepemimpinan sebagai innovator lebih optimal.
Dan berdasarkan masa kerja sebagian besar telah memiliki masa kerja diatas 21 tahun yaitu sebesar $12,1 \%$ atau 10 responden, sedangkan yang lainnya untuk masa kerja kurang dari 4 tahun sebesar $18,1 \%$ atau 15 responden, masa kerja antara $4-12$ tahun sebesar $45,8 \%$ atau 38 responden dan masa kerja antara 13 - 21 tahun sebesar $24,1 \%$ atau 20 responden. Data tersebut mengindikasikan bahwa staf-staf UMT Kota Tangerang masih termasuk produktif apabila mau berkreasi sebagaimana pendapat Vroom (dalam As'ad,2001), biasanya orang yang memiliki kinerja tinggi disebut orang yang produktif dan sebaliknya orang yang levelnya tidak mencapai standar dikatakan sebagai orang yang tidak produktif. Dengan berusaha melakukan cara-cara baru dan kreatif menurut Mc.Cleland (dalam Sutrisno, 2009) dapat dilakukan oleh staf-staf UMT Kota Tangerang, apabila ingin lebih berprestasi lagi menuju staf yang professional.

\section{Berdasarkan deskripsi variabel Penelitian}

Hasil penelitian menunjukan bahwa memang ada pengaruh yang positif dan signifikan antara disiplin kerja, motivasi, dan kepemimpinan terhadap kinerja staf UMT. Hal ini sejalan dengan pendapat Simanjutak (2005) bahwa kinerja bisa dipengaruhi beberapa faktor diantaranya adalah Kepemimpinan, Motivasi, Etos kerja, Fasilitas kerja dan Kondisi Kerja. Dalam penelitian ini menunjukan variabel disiplin kerja lebih dominan mempengaruhi kinerja staf dari pada variabel kepemimpinan dan motivasi. Hal ini dapat dilihat pada hubungan secara simultan bahwa nilai variabel sikap kerja dapat meningkatkan skor kinerja staf sebesar 0,322, variabel motivasi dapat meningkatkan skor kinerja staf sebesar 0,119, variabel kepemimpinan dapat meningkatkan skor kinerja staf sebesar -0,210.

Pengaruh sikap kerja lebih dominan ini memberikan gambaran bahwa sikap kerja yang merupakan salah satu fungsi dari manajemen sangat penting dalam pengelolahan suatu organisasi. Sikap kerja harus mampu menciptakan situasi kerja yang baik, sehingga staf-staf dapat melaksanakan tugas administrasi dengan baik dan dengan tenang. Disamping itu seorang staf dituntut untuk dapat bekerja sama dengan yang lainnya agar tujuan organisasi dapat tercapai. Hal ini sejalan dengan pendapat Wahyusumidjo yang mengemukakan bahwa agar fungsi staf dapat berhasil dalam memberdayakan sumber daya manusia untuk mencapai tujuan sesuai dengan situasi yang diperlukan seorang staf yang memiliki kemampuan profesional yaitu , kepribadian , keahlian dasar, pengalaman, pelatihan dan pengetahuan professional serta kompetensi administrasi dan pengawasan.

Kinerja staf dapat ditingkatkan melalui kemampuan manajerial kinerja staf dalam mengelolah organisasi dengan mendorong peningkatan kompetensi staf dan memotivasi staf untuk meningkatkan prestasi kerjanya. Hal ini sejalan dengan pendapat dari Anwar Prabu Mangkunegara, (2000:134) bahwa salah satu factor pendukung terciptanya produktivitas tinggi adalah peran kinerja staf yang mampu menampilkan hasil yang professional. Eksistensi staf semakin penting ketika dihadapkan pada situasi keragaman, karakteristik dan kemampuan yang dimiliki oleh anggota, namun masingmasing dituntut untuk tetap dapat berkontribusi secara optimal bagi organisasinya. Dalam paradigm lama staf 
diartikan sebagai kemampuan atau kesiapan yang dimiliki seseorang untuk melayani orang lain dengan memotivasi, menggerakan, mengajak dan menuntun untuk melakukan tindakan sesuatu. Dalam kondisi sekarang staf bukan saja memiliki kemampuan untuk mempengaruhi tetapi yang lebih penting adalah kemampuan member inspirasi kepada pihak lain, agar mereka secara produktif tergugah untuk melakukan berbagai tindakan demi tercapainya visi, misi dan tujuan dari organisasi.

Temuan penelitian ini diperkuat oleh pernyataan yang dikemukakan oleh Muhamad Surya (2003:137) bahwa kompetensi staf adalah pengetahuan, sikap dan penampilan yang ada pada seseorang agar dapat menunjukan kepribadian sebagai staf.

Aspek lain yang berhubungan erat dengan profesi staf yang juga mempunyai pengaruh positif terhadap kinerja staf adalah motivasi. Staf yang memiliki motivasi tinggi dalam mengajar akan memperlihatkan unjuk kerja yang jauh berbeda dari staf yang memiliki motivasi rendah. Staf yang memiliki motivasi tinggi akan memiliki pandangan positif dan melaksanakan tugas sebagai sesuatu yang menyenangkan. Staf yang memiliki motivasi tinggi akan memandang berbagai kekurangan instansnya sebagai tantangan, ia akan berusaha sedapat mungkin untuk mengatasi kekurangan tersebut. Robbin (dalam Hasibuan 2007) menyebutkan bahwa motivasi merupakan kerelaan berusaha seoptimal mungkin dalam mencapai tujuan organisasi yang dipengaruhi oleh kemampuan usaha dalam memuaskan kebutuhan individu.

Temuan penelitian bahwa kontribusi variabel motivasi sebesar 0,119, artinya tinggi rendahnya kinerja staf dijelaskan oleh variabel motivasi oleh karena itu untuk mengoptimlakan kinerja staf maka staf yang bersangkutan harus memmpunyai motivasi tinggi baik secara eksternal maupun internal. Sebagai staf dalam melaksanakan fungsi dan tugasnya harus mampu memotivasi dirinya secara maksimal, sehingga akan memiliki dorongan untuk mengoptimalkan kemampuannya. Simamora (2008) menyatakan bahwa motivasi adalah dorongan psikologis yang menggerakan seseorang pada tujuan. Apabila staf diberi motivasi namun tidak sesuai dengan kebutuhannya, maka pemberian motivasi akan berlangsung sia-sia tanpa hasil, terlebih jika tidak diberikan motivasi kinerja staf akan semakin menurun. Sesuai dengan hasil penelitian bahwa motivasi berpengaruh positif dan signifikan terhadap kinerja staf UMT Kota Tangerang. Semakin tinggi motivasi staf semakin tinggi pula kinerjanya dan sebaliknya.

Dalam konteks organisasi dalam mengoptimalkan motivasi adalah dengan memperlihatkan dan menindaklanjuti hal-hal yang sangat berpengaruh terhadap motivasi, misalnya staf diperlakukan dengan adil dan bijaksana dalam pemberian gaji atau insentif, pemberian fasilitas kerja dan termasuk didalamnya menciptakan kondisi kerja yang nyaman dan kondusif. Motivasi bisa juga dilakukan dengan pemberian penghargaan oleh Pimpinan lembaga atas prestasi kerjanya dan adanya komitmen pemimpin untuk menciptakan suasana organisasi pendidikan pada aspek kualitas. Oleh karena itu pimpinan instansi dituntut untuk dapat memberikan rangsangan dan dorongan agar motiovasi kerja staf lebih optimal, sehingga para staf dapat melaksanakan tugas yang lebih baik dan mengembangkan kemampuannya dalam melaksanakan pekerjaanya serta bangga terhadap pekerjaannya.

Dengan demikian kinerja staf dapat ditingkatkan melalui peningkatan kompetensi staf seperti memberikan insentif atau beasiswa kepada staf untuk melanjutkan pendidikan kejenjang yang lebih tinggi, mengikutsertakan dalam pelatihan-pelatihan profesionalisme staf. Motivasi kerja dapat meningkatkan kinerja staf dengan mendorong staf untuk meningkatkan prestasi kerjanya, mendorong staf untuk melakukan karya inovatif dalam pembelajaran dan memberikan penghargaan kepada staf yang berprestasi serta secara bersama-sama membuat rencana dan menetapkantujuan yang akan dicapai sekolah. Sedangkan Kepemimpinan lembaga dapat meningkatkan kinerja staf dengan mengoptimalkan tugas pokoknya yaitu sebagai educator, manajer, administrator, supervisor, leader. Innovator dan motivator.

\section{DAFTAR PUSTAKA}

1) Bittel, Lester, Robert, Encyelopedia Of Prefosional Manajemen mr, Graw hill, 2, 208 Stoner James, A,F OP, cet, 11, 12.

2) Danim, Sudarwan, 2004, Motivasi Kepemimpinan Evektivitas kelompok, Jakarta Rineke cipta.

3) Danim Sudarwo, 2005, Motivasi, Kepemimpinan dan Efektivitas, Kelompok, Jakrta, Rineke, Cip.

4) Danis, Sudarwan, 2004 Motivasi, Kepemimpinan dan Efektivitas, Kelompok, Jakarta, Rineke, Cipta.

5) Darwan Wibisono 2009 Manajemen Kinerja Konsep, Desain dan Teknik, Meningkjatkan Daya Saing Perusahaan, Jakarta Erlangga.

6) Desy Fernanda 2003, Etika Organisasi Pemerintah Jakarta, Lembaga Administrasi Negara Republik Indonesia.

7) Fairhalm, Gilbert no: 2001.Leadeship, And The Culture Of Turst, Preager Publiserhr.

8) Fairhon, Gilbert, W. Leadeship and the cultur of Turst, Preagar Publiseher 2004.

9) Ficeder. Fred Martin M. Chmer, 2001, Leadership and Effective, Manajemen, Bi, Scoott, Fores. Manard Company, Glirnvi e W. Lileonis.

10) Gibson, Ivancevic dan Dannely 2008, alih bahasa Djoerban Wahid.

11)Gibson Etal 2001, Organisasi, jilid 1 dan 2 alih bahasa Agus Dhama Erlangga, Jakrta.

12) Graham, Gerald dalam Arep dan Hendri Tanjung, 2002 Manajemen Sumber Daya Manusia, Jakrta : penerbit Universitas Trisakti.

13)Hersey, Paul, Keneth, Blarchard, Manajemen Of Organization Behavior, Prentice, hal, inc. Engle Wood Elits, New, Jersey 1977.

14)Himpunan Keputusan Menteri Kehutanan Bidang Kepegawaian di lingkungan Departemen Kehutanan, jakarta, Sekretaris Jendral Departemen Kehutanan, Republik Indonesia.

15)Japan Assia Ciation For civil Service Training and Development, 2008, dalam Modul " Hawta Win Confidence As, Govermen Official " Shet, no. 80.

16) Ketentuan pelaksanaan peraturan pemerintah nomor: 100. Tahun 2000, tentang Pengangkatan Pegawai Negeri Sipil, dalam,Jabatan Struktural, Sebagaimana 
telah diubah dengan peraturan pemerintah nomor: 13 tahun 2007 Jakarta.

17)Kreatif Produktivitas, 30, 30 Toto Tasmara, 1994,Etos Kerja Pribadi Muslim, Yogyakarta, PT. Dana Abadi Wakaf.

18)Kusriyanto, Bambang, 2003, Peningkatan Karyawan, Jakarta Pustaka, Binawan Persindo.

19)Maher, F, Maser, 2001, Democracy and Publiservice Paragamon new York.

20)Mahmudi, 2005, Manajemen Kinerja Sektor Publik Yogyakarta, UPI,AMP, YKPN.

21)Malayu SP,Hasibuan 2001 Manajemen Sumber Daya Manusia, Jakarta, Bumi Aksara.

22)Mangku Negara, AA Anwar P. 2000. Manajemen Sumber Daya Manusia Perusahaan, Bandung : PT. Remaja.

23)Masher, F, Maser, 2006, Etic, Democracy and Publik Service Paragamon, New York.

24)Maslow, Abraham H. 1970. Motivation and Personality, dalam J. Winardi, 2000. Motivasi dan Permotivasian dalam Manajemen, Jakarta : PT. Grafindo Persada.

25)Mulyana, Maulid, 1994" Penerapan Produktivitas Dalam Organisasi, Jakarta Bumi Aksara.

26)Mulyana Mauled, 1993. Penerapan Produktivitas Dalam Organisasi. Jakarta Bumi Aksara.

27)Nation, Sahlan, 2007, Teori Motivasi dalam pendekatan Psykologis dan Organisasi Jakarta studia perss.

28)Rafianto, Jhon 1985, Produktivitas dan Tenega Kerja Organisasi, Isu Teori dan Solusi, Yogyakarta, Amara Book.

29)Ridwan, 2006. Metode dan teknik Menyusun Tesis. Bandung: Alfabeta.

30)Rigg, W. Fred 2008 Administrasi, Negara - Negara, Berkembang, Teoti asyarakat Primatic, Jakarta, CV. Rajawali.

31)Rigg. W. Fred 2006,Negara - negara Berkembang Teori Masyarakat Primatics, Jakarta, Raja Wali. 